\title{
Persepsi Kegunaan dan Kemudahan Menggunakan terhadap Niat Menggunakan Mobile Payment dimasa Pandemi Covid-19
}

\section{Muhammad Nurhaula Huddin ${ }^{1 *}$, Martina Rahmawati Masitoh $^{1}$}

Fakultas Ekonomi dan Bisnis, Universitas Serang Raya, Banten, Indonesia

*Corresponding author: haulahuddin@gmail.com

\section{Article history}

Received, 08 March 2021

Revised 1, 22 April 2021

Revised 2, 03 June 2021

Accepted, 14 July 2021

\begin{abstract}
Technological developments have changed the human behavior to consume products and services, from offline transactions to online transactions. The purpose is to examine the impact of perceived usefulness and perceived ease of use on attitude and examine its impact on intention to use mobile payments. The population in this study are customers who use mobile payment in Banten Province, especially Gopay and OVO. This study uses purposive sampling technique in determining the research sample. In this study, we obtained 243 respondents from mobile payment user in Banten Province. Using partial leats square structural equation modeling (PLS-SEM), the researcher found that there is significant influence between perceived usefulness and ease of use on attitudes towards mobile payments. This study also found that attitudes have a significant influence on intention to use mobile payments.
\end{abstract}

Keyword: usefulness, ease of use, attitude, intention, mobile payment

Abstrak

Perkembangan teknologi telah mengubah perilaku konsumsi individu terhadap produk dan jasa dari transaksi offline ke transaksi online. Penelitian ini bertujuan untuk menganalisis dan menguji pengaruh persepsi kegunaan dan kemudahan menggunakan terhadap sikap dan menguji dampaknya terhadap niat menggunakan layanan pembayaran mobile. Populasi dalam penelitian ini merupakan pelanggan yang menggunakan layanan pembayaran mobile di Provinsi Banten khususnya Gopay dan OVO. Penelitian ini menggunakan teknik purposive sampling dalam menentukan sampel penelitian. Pada penelitian ini, data yang digunakan sebanyak 243 pelanggan pembayaran mobile di Provinsi Banten. Menggunakan partial leats square structural equation modeling (PLS-SEM), peneliti menemukan bahwa ada pengaruh yang signifikan antara persepsi kegunaan dan kemudahan menggunakan pada sikap terhadap pembayaran mobile. Studi ini juga menemukan bahwa sikap memiliki pengaruh terhadap niat menggunakan pembayaran mobile.

Kata kunci: Persepsi Kegunaan, Persepsi Kemudahan menggunakan, Sikap, niat, pembayaran mobile

\section{Cite this article:}

Huddin, M.N., Masitoh, M.R (2021). Persepsi Kegunaan dan Kemudahan Menggunakan terhadap Niat Menggunakan Mobile Payment dimasa Pandemi Covid-19, Jurnal Al-Qardh, 6(1), 1-16. https://doi.org/10.23971/jaq.v6i1.2699

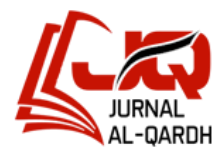

pISSN: $2354-6034$ eISSN: 2599 - 0187 


\section{Pendahuluan}

Teknologi terus berubah mengalami perkembangan yang sangat cepat dan massive, dimana perubahan dan inovasi terus terjadi setiap waktu, dan manusia tidak lepas dari penggunaan teknologi dalam kehidupan sehari hari, Hampir setiap aspek kehidupan kerap bersinggungan dengan teknologi. Dewasa ini salah satu teknologi yang tidak bisa dilepaskan dari kehidupan sehari hari adalah internet. Porter berpendapat bahwa teknologi internet memberikan peluang yang lebih baik bagi perusahaan untuk membangun posisi strategis yang khas dibandingkan dengan generasi teknologi di masa lalu. ${ }^{1}$ Dimana teknologi internet dapat memberikan dampak yang positif bagi perusahaan untuk membangun keunggulan kompetitif untuk tetap bersaing.

Saat ini, Internet telah merevolusi cara suatu bisnis dijalankan dan penggunaannya menjadi semakin penting bagi keberhasilan bisnis perusahaan. Internet adalah alat yang paling kuat yang saat ini tersedia untuk meningkatkan efektivitas operasional. ${ }^{2}$ Perusahaan memiliki jangkauan pasar yang luas berkat kehadiran internet, jika dahulu perusahaan beroperasi dengan cara menjual produk atau jasa secara konvensional dengan membuka toko atau gerai yang di tempatkan di posisi yang dirasa strategis. Kehadiran teknologi internet yang merambah secara luas memungkinkan perusahaan menjual produk ataupun jasa mereka baik secara konvensional ataupun online secara bersamaan. Tetapi, teknologi internet bukan merupakan pondasi fundamental dalam rantai dan operasional perusahan melainkan menjadi pelengkap dari rangkaian operasional yang sudah ada. ${ }^{3}$

Pertumbuhan jumlah pengguna internet terjadi sangat signifikan, di Indonesia dalam rentang waktu 1998 - 2017 jumlah pengguna internet mencapai 143,26 juta jiwa. Dengan lebih dari $50 \%$ Perangkat yang digunakan pengguna dalam mengakses internet adalah smartphone, dimana mayoritas perilaku penggunaan internet terfokus pada layanan ekonomi seperti aktivitas mencari harga $(45,14 \%)$, membantu pekerjaan $(41,04 \%)$, informasi membeli $(37,82 \%)$, beli online $(32,19 \%)$, dan jual online $(16,83 \%){ }^{4}$ Pertumbuhan jumlah pengguna internet yang tinggi ini mendorong perusahaan untuk menggunakan teknologi internet di dalam kegiatan operasional perusahaan. Hal ini memperlihatkan bahwa teknologi internet memainkan peranan penting dalam kegiatan ekonomi masyarakat Indonesia. Hal ini sejalan dengan survei yang dilakukan pada tahun sebelumnya, sebanyak 130,8 juta pengguna sudah mengetahui bahwa internet sebagai tempat menawarkan, mencari, atau jual beli barang dan jasa. Online shop menjadi konten komersial yang sering dikunjungi oleh 82,2 juta pengguna atau sebanyak 62 persen, di urutan berikutnya adalah konten bisnis personal, yang dikunjungi 45,3 juta pengguna atau sebanyak $34,2 \% .^{5}$

Secara umum, terlihat bahwa perilaku masyarakat Indonesia telah mengalami pergeseran dari offline menjadi online dalam melakukan transaksi ekonomi karena perkembangan teknologi internet yang semakin cepat. Pertumbuhan pasar jual beli online di Indonesia dan pola transaksi online yang juga terus bertumbuh, memunculkan peluang bagi para perusahaan jasa keuangan dalam memberikan layanan jasa keuangan (financial service). Beberapa tahun terakhir industri jasa keaungan telah merambah dunia jasa keuangan digital atau kerap disebut dengan fintech yang di definisikan

\footnotetext{
${ }^{1}$ Porter, M. E. 2001. Strategy and the internet. Harvard Business Review, March: 62-78.

${ }^{2}$ Ibid.

${ }^{3}$ Ibid.

${ }^{4}$ APJII. 2017. Infografis: penetrasi \& perilaku pengguna internet Indonesia survey 2017. Retrieved April 20, 2018, from https://apjii.or.id/content/read/39/342/Hasil-Survei-Penetrasi-dan-Perilaku-Pengguna-Internet-Indonesia-2017

${ }^{5}$ APJII. 2016. Infografis: penetrasi \& perilaku pengguna internet Indonesia survey 2016. Retrieved April 20, 2018, from https://apjii.or.id/content/read/39/264/Survei-Internet-APJII-2016.
} 
sebagai teknologi keuangan, adalah industri ekonomi yang terdiri dari perusahaan yang menggunakan teknologi untuk membuat layanan keuangan lebih efisien. ${ }^{6}$

Fintech dipandang sebagai pasar baru dimana pasar tersebut mengintegrasikan keuangan dan teknologi. ${ }^{7}$ Fintech memiliki banyak jenis, antara lain startup pembayaran, peminjaman (lending), perencanaan keuangan (personal finance), investasi ritel, pembiayaan (crowdfunding), remitansi, dan riset keuangan. Perkembangan fintech juga sejalan dengan perkembangan perangkat teknologi lainnya seperti perangkat mobile. ${ }^{8}$ Menurut Edy dalam riset yang telah dilakukan oleh Fintech id, layanan transaksi pembelian atau pembayaran yang dikelola oleh perusahaan pembayaran yang berbasis teknologi (payment gateway) telah berkembang pesat selama beberapa tahun terakhir. ${ }^{9}$ Terdapat kurang $44 \%$ dari total 120 perusahaan fintech di Indonesia adalah penyedia layanan pembayaran. Transaksi pembayaran online terbanyak dilakukan secara elektronik melalui smartphone, tablet atau perangkat genggam lainnya atau dikenal juga dengan istilah mobile payment. Mobile payment (m-payment) merupakan pembayaran barang, layanan, dan tagihan menggunakan perangkat seluler dengan memanfaatkan teknologi komunikasi nirkabel dan lainnya. ${ }^{10}$

Penelitian Daştan dan Gürler (2016) dan Aslam et al (2017) menunjukkan bahwa terdapat beberapa faktor penting yang dapat mendorong seseorang atau individu untuk menggunakan mobile payment sebagai sarana transaksi atau pembayaran, yakni persepsi kegunaan, persepsi kemudahan menggunakan, dan persepsi keamanan. ${ }^{11,12}$ Beberapa penelitian sebelumnya telah mengkonfirmasi bahwa persepsi kemudahan menggunakan memiliki efek yang kuat pada persepsi kegunaan dimana dalam aplikasinya sangat menekankan manfaat yang di dapat dari kedua faktor tersebut. ${ }^{13,14}$ Misalnya, dalam melakukan pembelian atau pembayaran pulsa, seseorang tidak perlu repot untuk membeli pulsa ke konter pulsa, cukup dengan membeli melalui aplikasi yang menyediakan pulsa atau e-commerce yang juga menyediakan penjualan pulsa dapat membeli dan membayarnya secara langsung menggunakan saldo yang dimilikinya. Hal ini memberikan manfaat yang besar karena pembelian dan pembayaran bisa dilakukan dengan praktis, cepat dan kapan saja dibutuhkan walau tanpa memegang uang tunai.

Penggunaan mobile payment di Indonesia masih terbilang baru karena merupakan salah satu inovasi baru dalam dunia pembayaran yang masih membutuhkan waktu penerimaan bagi sebagian masyarakat. Lebih jauh, karena inovasi teknologi tersebut masih dipertanyakan tentang keamanan dalam melakukan transaksi pembayaran mobile. Venkatesh dan Davis (2000) mengatakan sebagian besar penelitian sebelumnya menunjukkan bahwa sikap memiliki dampak positif yang signifikan

\footnotetext{
${ }^{6}$ McAuley, D. 2014. What is FinTech? Wharton FinTech.

${ }^{7}$ Arner, D. W., Barberis, J., \& Buckley, R. P. 2015. The Evolution of FinTech: A New Post-Crisis Paradigm? University of Hong Kong Faculty of Law Research Paper No. 2015/047.

${ }^{8}$ Dapp, (2014). Fintech-The Digital (r)evolution in the financial sector. Frankfurt : Deutche Bank Research.

${ }^{9}$ Edy. 2017. Kegiatan Pembayaran Gaya Baru dalam Dunia Fintech. Fintech Indonesia. Retrieved April 20, 2018, from https://fintech.id/ideas/ideas-detail?id=158

${ }^{10}$ Dahlberg, T., Mallat, N., Ondrus, J., \& Zmijewska, A. 2008. Past, present and future of mobile payments research: a literature review. Electronic Commerce Research and Applications 7 (2), 165-181.

${ }^{11}$ Dastan, İ., \& Gürler, C. (2016). Factors Affecting the Adoption of Mobile Payment Systems: An Empirical Analysis. EMAJ: Emerging Markets Journal, (1), 16-24.

${ }^{12}$ Aslam, W., Ham, M., \& Arif, I. 2017. Consumer Behavioral Intentions towards Mobile Payment Services: An Empirical Analysis in Pakistan. Market. Tržište, 29 (2), 161-176.

${ }^{13}$ Davis, F.D. 1989. Perceived usefulness, perceived ease of use, and user acceptance of information technology. MIS Quarterly, 13, 319-340.

${ }_{14}$ Gefen, D., Karahanna, E., \& Straub, D.W. 2003. Trust and TAM in online shopping: an Integrated model. MIS Quarterly, 27, 51-90.
} 
terhadap niat perilaku individu. ${ }^{15}$ Niat penggunan oleh calon konsumen tergantung pada sikap konsumen. Sikap konsumen terhadap penggunaan dan niat untuk menggunakan layanan pembayaran mobile harus memiliki hubungan yang positif secara signifikan. Ketika konsumen merasakan hal positif, mereka akan percaya bahwa menggunakan layanan pembayaran mobile adalah pengalaman yang baik dan meningkatkan kesediaan mereka untuk menggunakannya. Ketika seseorang memiliki sikap positif yang lebih tinggi terhadap penggunaan teknologi baru, niat perilaku akan relatif lebih tinggi. ${ }^{16}$

Secara empiris, beberapa penelitian sebelumnya menunjukkan bahwa persepsi kegunaan dan persepsi kemudahan menggunakan merupakan elemen penting dari penerimaan sebuah teknologi. ${ }^{17}$ Namun, belum banyak penelitian yang menguji kedua faktor tersebut pada konteks mobile payment yang ada di Indonesia. Oleh karena itu, penelitian ini bertujuan untuk menguji pengaruh persepsi kegunaan dan persepsi kemudahan menggunakan terhadap sikap dan dampaknya terhadap niat menggunakan layanan pembayaran mobile.

\section{Metode Penelitian}

Penelitian ini dilakukan dengan menggunakan pendekatan kuantitatif dengan menggunakan data primer yang dikumpulkan dengan metode survei dalam jaringan melalui penyebaran kuesioner dalam format google document. Populasi dalam penelitian ini merupakan pelanggan yang menggunakan layanan pembayaran mobile di Provinsi Banten yang terfokus pada layanan Gopay dan OVO. Teknik sampling yang digunakan pada penelitian ini adalah teknik purposive sampling yang bersifat penilaian menggunakan kriteria-kriteria untuk dapat dijadikan sebagai sampel penelitian. ${ }^{18}$ Kriteria tersebut meliputi individu yang belum pernah menggunakan layanan pembayaran mobile dan menggunakannya di lokasi yang menjadi wilayah sampel yaitu Provinsi Banten. Ghozali dan Fuad (2005) menyarankan jumlah sampel 5-10 kali dari jumlah pernyataan yang digunakan jika analisanya dilakukan dengan permodelan structural equation modeling (SEM). ${ }^{19}$ Dengan begitu, jumlah sampel minimal dalam penelitian ini adalah 80 sampai 16 responden.

Penelitian ini menggunakan empat variabel yang terdiri atas 3 eksogen dan 1 variabel endogen. Variabel eksogen meliputi persepsi kegunaan, persepsi kemudahan menggunakan dan sikap, sedangkan variabel endogen nya adalah niat. Aslam et al., (2017) mendefinisikan masing-masing variabel seperti di bawah ini. ${ }^{20}$ Persepsi kegunaan merupakan tingkat keyakinan individu terhadap manfaat yang didapatkan ketika menggunakan suatu teknologi. Persepsi kemudahan menggunakan merupakan tingkat keyakinan individu terhadap kemudahan yang didapatkan ketika menggunakan suatu teknologi. Sikap merupakan perasaan positif atau negatif yang dihasilkan ketika

\footnotetext{
${ }^{15}$ Venkatesh, V., \& Davis, F.D. 2000. A theoretical extention of the technology acceptance model: four longitudinal field studies. Management Science, 46, 186-204.

${ }^{16}$ Chuang L-M, Liu C-C, \& Kao H-K. 2016 The adoption of fintech service: TAM perspective. Int J Manag Adm Sci $3: 1-15$

${ }^{17}$ Davis, F.D. 1989. Perceived usefulness, perceived ease of use, and user acceptance of information technology. MIS Quarterly, 13, 319-340.

${ }^{17}$ Gefen, D., Karahanna, E., \& Straub, D.W. 2003. Trust and TAM in online shopping: an Integrated model. MIS Quarterly, 27, 51-90.

${ }^{17}$ Venkatesh, V., \& Davis, F.D. 2000. A theoretical extention of the technology acceptance model: four longitudinal field studies. Management Science, 46, 186-204.

${ }^{18}$ Sugiyono. 2015. Metode Penelitian Kuantitatif, Kualitatif dan R\&D. Bandung: Alfabeta.

${ }^{19}$ Ghozali, I., dan Fuad. 2005. Structural Equation Modelling: Teori, Konsep dan Aplikasi. Semarang: Badan Penerbit Universitas Diponegoro.

20 Aslam, W., Ham, M., \& Arif, I. 2017. Consumer Behavioral Intentions towards Mobile Payment Services: An Empirical Analysis in Pakistan. Market. Tržište, 29 (2), 161-176.
} 
seseorang menggunakan teknologi baru. Intensi merupakan niat individu untuk mengkonsumsi suatu produk atau jasa dengan menggunakan teknologi. Masing-masing variabel diukur dengan menggunakan empat item pernyataan, dimana pengukurannya menggunakan skala likert.

Data pada penelitian ini dianalisis dengan menggunakan partial least square (SEM-PLS) (WarpPLS 5.0). Hal ini dilakukan karena memungkinkan peneliti untuk melakukan pengujian secara serentak terhadap seluruh sistem variabel, yakni dengan model pengukuran dan model struktural. ${ }^{21}$ Model pengukuran dilakukan untuk menguji validitas dan reliabilitas dari setiap indikator pengukuran terhadap variabelnya. Mode struktural dilakukan untuk menguji kelayakan model yang ditunjukkan dengan nilai goodness of fit, mengetahui arah hubungan antar variabel dalam model yang ditunjukkan dengan nilai koefisien determinasi ( $R$-squared), dan pengujian hipotesis yang dilakukan dengan menggunakan nilai koefisien jalur dan nilai signifikansi ( $p$ value).

\section{Tinjauan Pustaka}

\section{Technology Acceptance Model (TAM)}

Technology acceptance model (TAM) adalah salah satu model penelitian pertama dan paling berpengaruh untuk menjelaskan perilaku pengguna atau konsumen dalam mengadopsi suatu teknologi. ${ }^{22}$ Model ini memberikan pemahaman yang luas mengenai bagaimana individu menerima dan menggunakan suatu teknologi. ${ }^{23}$ TAM mampu menelusuri beragam faktor yang dapat menjelaskan perilaku individu terhadap suatu teknologi, mulai dari faktor eksternal terhadap internal beliefs, sikap dan niat.

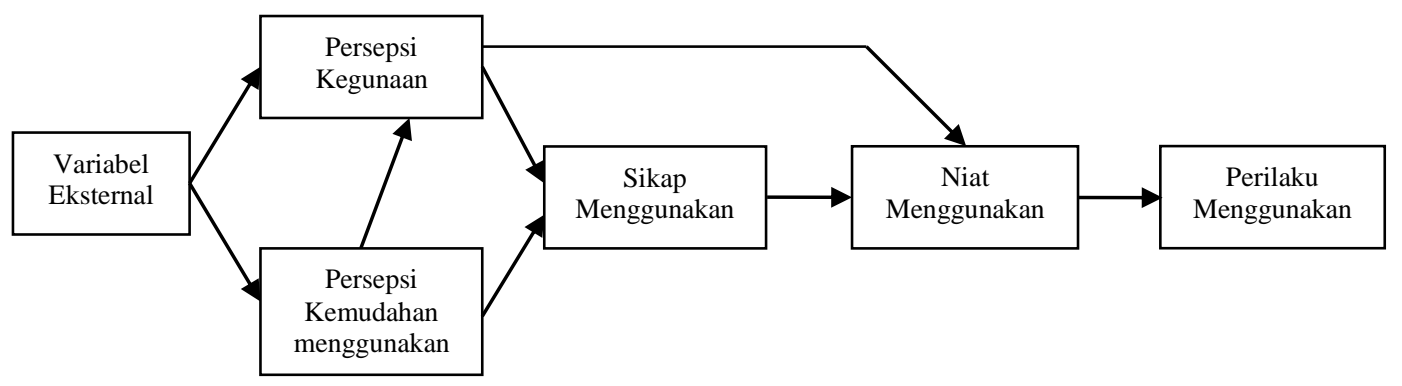

\section{Gambar 1. Model Penerimaan Teknologi}

Sumber: Davis et al., (1989)

Perilaku individu dalam menggunakan suatu teknonogi sangat bergantung pada niat dan niat ditentukan oleh sikap dan internal beliefs mereka terhadap teknologi. Dasar pemikiran TAM adalah bahwa pengguna akan bertindak secara rasional ketika mereka memutuskan untuk menggunakan suatu teknologi. Dalam teori TAM, dua variabel utama yakni persepsi kegunaan dan persepsi kemudahan menggunakan adalah faktor yang paling menonjol dan menentukan pada niat individu dalam mengadopsi dan menggunakan suatu teknologi.

${ }^{21}$ Sholihin, M., \& Ratmono, D. 2013. Analisis SEM-PLS dengan warpPLS 3.0: untuk hubungan nonlinier dalam penelitian sosial dan bisnis. Yogyakarta, ANDI.

${ }^{22}$ Davis, F.D., Bagozzi, R.P., \& Warshaw, P.R. 1989. User acceptance of computer technology: a comparison of two theoretical models. Management Science, 35, 982-1003.

${ }^{23}$ Ibid. 


\section{Persepsi Kegunaan}

Davis et al.,(1989) mendefinisikan persepsi kegunaan sebagai "the degree to which a person believe that using a particular system would enhance his or her job performance". ${ }^{24}$ Hal ini menandakan bahwa persepsi kegunaan memiliki efek langsung pada niat individu untuk mengadopsi suatu teknologi, bahwa dengan menggunakan suatu teknologi kebutuhan ataupun aktivitas yang dilakukan oleh seorang individu akan sangat terbantu. Contohnya, aplikasi pembayaran hadir bagi individu yang sibuk dan tidak memiliki banyak waktu luang untuk antri dan membayar tagihan listrik, maka dari itu mereka dapat melakukan pembayaran melalui aplikasi mobile payment dimana hal tersebut memberikan manfaat yang besar bagi mereka.

\section{Persepsi Kemudahan Menggunakan}

Persepsi kemudahan menggunakan didefinisikan "the degree to which a person believes that using a particular system would be free of effort". ${ }^{25}$ Kemudahan menggunakan berarti kebebasan dari kerumitan dan masalah. Dengan demikian, teknologi yang dianggap lebih mudah digunakan akan lebih mudah diterima secara umum dan digunakan oleh lebih banyak orang. Zhu et al., (2012) menambahkan bahwa Persepsi kemudahan menggunakan menandakan tingkat di mana seorang individu menerima bahwa menggunakan teknologi tertentu akan mudah dan tidak merepotkan. ${ }^{26}$

Dengan menggunakan suatu teknologi individu akan mudah mendapatkan suatu produk atau layanan yang mereka inginkan. Contohnya, pada sistem pembayaran mobile payment, seseorang hanya membutuhkan device berupa perangkat seluler untuk membayar belanjaannya. Hal ini menunjukkan bahwa sistem pembayaran tersebut membuat individu lebih mudah mendapatkan produk atau jasa yang mereka butuhkan tanpa harus mengeluarkan banyak usaha. ${ }^{27,28}$ Berdasarkan hal tersebut, TAM adalah model yang tepat untuk menguji penerimaan dan niat dalam menggunakan layanan mobile payment.

\section{Sikap}

Sikap adalah Perasaan positif atau negatif yang dihasilkan ketika seseorang menggunakan teknologi baru. Ketika seseorang memiliki sikap positif yang lebih tinggi terhadap penggunaan teknologi baru, niat perilaku akan relatif lebih tinggi. ${ }^{29}$ Sikap mencerminkan perasaan suka atau tidak suka yang dicerminkan individu melalui perilaku mereka, ${ }^{30}$ hal ini menyiratkan bahwa sikap berkembang seiring waktu ketika orang mendapatkan pengalaman.

Allport (1935) mendefinisikan sikap sebagai kondisi kesiapan mental dan saraf yang dikembangkan melalui pengalaman, yang memberikan pengaruh dinamis atau

\footnotetext{
${ }^{24}$ Ibid.

${ }^{25}$ Davis, F.D. 1989. Perceived usefulness, perceived ease of use, and user acceptance of information technology. MIS Quarterly, 13, 319-340.

${ }^{26}$ Zhu, D. Linb, C. T \& Hsu, Y. 2012. Using the technology acceptance model to evaluate user attitude and intention of use for online games. Total Quality Management.

${ }^{27}$ Davis, F.D., Bagozzi, R.P., \& Warshaw, P.R. 1989. User acceptance of computer technology: a comparison of two theoretical models. Management Science, 35, 982-1003.

${ }^{28}$ Davis, F.D. 1989. Perceived usefulness, perceived ease of use, and user acceptance of information technology. MIS Quarterly, 13, 319-340. $3: 1-15$.

${ }^{29}$ Chuang L-M, Liu C-C, \& Kao H-K. 2016 The adoption of fintech service: TAM perspective. Int J Manag Adm Sci

${ }^{30}$ Fishbein, M. 1963. An investigation of the relationship between beliefs about an ob-ject and the attitude toward that object. Human Relations, 16, 233-9.
} 
terarah pada respons individu. ${ }^{31}$ Sikap adalah keyakinan bahwa individu telah memperoleh hasil dari mengadopsi perilaku tertentu. ${ }^{32}$ Lebih juah, mereka mengemukakan meskipun model teoritis antara TAM, TRA dan TPB berbeda tetap ketiga model tersebut menunjukkan bahwa sikap adalah anteseden utama dari niat untuk terlibat dalam perilaku tertentu. ${ }^{33}$

\section{Pengembangan Hipotesis}

Persepsi kegunaan menjelaskan bahwa pengguna potensial menganggap teknologi baru berguna pada kinerja pekerjaan dan mereka bisa mendapatkan manfaat di masa depan. ${ }^{34,35}$ Pengguna percaya bahwa manfaat yang diberikan oleh layanan pembayaran mobile bermanfaat, misalnya dalam melakukan pembelian atau pembayaran pulsa, seseorang tidak perlu repot repot membeli pulsa ke konter pulsa, cukup dengan membeli melalui aplikasi yang menyediakan pulsa atau e-commerce yang juga menyediakan pulsa di dalamnya lalu membayarnya secara langsung menggunakan saldo yang ia miliki.

Layanan pembayaran mobile memberikan manfaat yang besar karena pembelian dan pembayaran bisa dilakukan dengan praktis, mudah, cepat dan kapan saja dibutuhkan. Jika konsumen percaya bahwa sistem pembayaran mobile lebih berguna untuk aktivitas mereka, sikap mereka terhadap penggunaan sistem pembayaran seluler akan positif dan kecendrungan untuk menggunakan layanan pembayaran mobile juga lebih tinggi. Dengan begitu, manfaat yang dirasakan dari layanan pembayaran mobile adalah faktor kognitif bagi konsumen untuk menerima sistem tersebut. Studi sebelumnya juga menegaskan bahwa ada hubungan yang signifikan antara persepsi kegunaan dan adopsi teknologi. ${ }^{36,37,38,39}$ Berdasarkan uraian di atas, peneliti merumuskan hipotesis sebagai berikut.

H1: Persepsi kegunaan berpengaruh positif terhadap sikap menggunakan layanan pembayaran mobile

Persepsi kemudahan menggunakan mengacu pada tingkat pengguna potensial yang menganggap teknologi baru itu mudah digunakan. ${ }^{40,41}$ Pengguna percaya bahwa manfaat yang diberikan oleh layanan pembayaran mobile mudah untuk digunakan, misalnya mereka dapat menggunakan aplikasi sistem pembayaran mobile tanpa panduan orang lain, user interface yang tidak membingungkan, mudah untuk di operasikan, serta prosedur transaksi yang sederhana. Mengingat keterbatasan teknis

\footnotetext{
${ }^{31}$ Allport, G. W. 1935. Attitudes. In C. M. Murchison (Ed.), Handbook of Social Psychology. Winchester, MA: Clark University Press.

${ }^{36}$ Aslam, W., Ham, M., \& Arif, I. 2017. Consumer Behavioral Intentions towards Mobile Payment Services: An Empirical Analysis in Pakistan. Market. Tržište, 29 (2), 161-176.

${ }^{37}$ Shanmugam, A., Savarimuthu, M., \& Wen, T. 2014. Factors Affecting Malaysian Behavioral Intention to Use Mobile Banking With Mediating Effects of Attitude. Academic Research International, 5(2), 236-253.

${ }^{38}$ Ramayah, T., \& Suki, N. M. 2006. Intention to use mobile PC among MBA students: implications for technology integration in the learning curriculum. UNITAR e-Journal, 1(2), 1-10.

${ }^{39}$ Taylor, S., \& Todd, P. A. 1995. Understanding information technology usage: A test of competing models. Information systems research, 6(2), 144-176. 38(4): 217-230

${ }^{40}$ Moon, J. W., \& Kim, Y. G. 2001. Extending the TAM for a World-Wide-Web Context. Information and Management,

${ }^{41}$ Venkatesh, V., \& Davis, F.D. 2000. A theoretical extention of the technology acceptance model: four longitudinal field studies. Management Science, 46, 186-204.
} 
perangkat mobile, kemudahan menggunakan menjadi pendorong penerimaan aplikasi mobile. ${ }^{42,43}$ Berdasarkan uraian di atas, peneliti merumuskan hipotesis sebagai berikut.

$\mathrm{H} 2$ : Persepsi kemudahan menggunakan berpengaruh positif terhadap sikap menggunakan layanan pembayaran mobile.

Ketika seseorang memiliki sikap positif yang lebih tinggi terhadap penggunaan teknologi baru, niat perilaku akan relatif lebih tinggi. ${ }^{44}$ Dalam Venkatesh dan Davis (2000) sebagian besar penelitian sebelumnya menunjukkan bahwa sikap memiliki dampak positif yang signifikan terhadap niat perilaku individu. ${ }^{45}$ Niat penggunan oleh calon konsumen tergantung sikap mereka. Sikap konsumen terhadap penggunaan dan niat untuk menggunakan layanan pembayaran mobile harus memiliki hubungan yang positif secara signifikan. Ketika konsumen merasakan hal positif, mereka akan percaya bahwa menggunakan layanan pembayaran mobile adalah pengalaman yang baik dan meningkatkan kesediaan mereka untuk menggunakannya.

Penelitian terdahulu telah mengidentifikasi hubungan positif antara sikap dan niat individu untuk menggunakan suatu produk atau layanan. ${ }^{46,47,48,49,50}$ Berdasarkan uraian di atas, peneliti merumuskan hipotesis sebagai berikut. mobile.

H3: sikap berpengaruh positif terhadap niat menggunakan layanan pembayaran

\section{Model Penelitian}

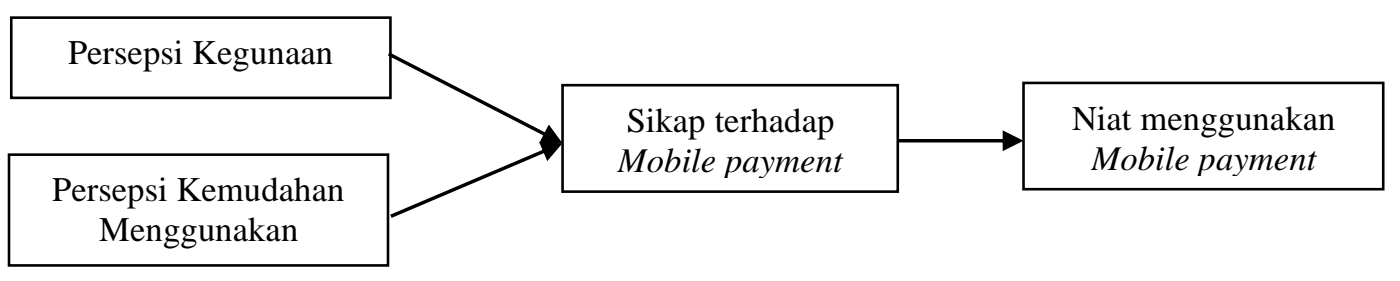

Gambar 1. Model Penelitian

\section{Hasil dan Diskusi}

Responden pada penelitian ini sangat bervariasi baik dari segi jenis kelamin, usia, pendidikan, pekerjaan dan pembayaran mobile yang digunakan. Dari 243 responden mayoritas didominasi oleh laki-laki yaitu sebanyak $137(56,4 \%)$ dan diikuti responden perempuan sebanyak $106(43,6 \%)$. Berdasarkan usia, responden usia dibawah 20 tahun sebanyak 144 (59,3\%), 21 s/d 35 sebanyak 99 (40,7\%) dan yang

\footnotetext{
42 Ibid.

43 Aslam, W., Ham, M., \& Arif, I. 2017. Consumer Behavioral Intentions towards Mobile Payment Services: An Empirical Analysis in Pakistan. Market. Tržište, 29 (2), 161-176. $3: 1-15$.

${ }^{44}$ Chuang L-M, Liu C-C, \& Kao H-K. 2016 The adoption of fintech service: TAM perspective. Int J Manag Adm Sci

${ }^{45}$ Venkatesh, V., \& Davis, F.D. 2000. A theoretical extention of the technology acceptance model: four longitudinal field studies. Management Science, 46, 186-204.

${ }^{46}$ Bauer, H. H., Reichardt, T., \& Schüle, A. 2005. User requirements for location based services. Proceedings of the IADIS International Conference in e Commerce, Porto, 211-218.

${ }^{47}$ Lie bana-Cabanillas F, Muñoz-Leiva F, \& Sa'nchez-Ferna'ndez J. 2015. Payment systems in new electronic environments: consumer behavior in payment systems via SMS. Int J Inf Technol Decis Mak 14:1-29. 12(2):165-187.

${ }^{48}$ Lorenzo-Romero C, Del Chiappa G. 2013 Adoption of social networking sites by Italian. Inf Syst e-Bus Manag

${ }^{49}$ Meharia, P. 2012. Assurance on the reliability of mobile payment system and its effects on its' use: an empirical examination. Account Manag Inf Syst Contab Si Inf De Gestiune 11(1):97-111.

50 Aslam, W., Ham, M., \& Arif, I. 2017. Consumer Behavioral Intentions towards Mobile Payment Services: An Empirical Analysis in Pakistan. Market. Tržište, 29 (2), 161-176.
} 
berusia diatas 35 tahun tidak ada. Berdasarkan tingkat pendidikan, responden dalam penelitian ini didominasi oleh lulusan SMA/SMK dan S1, kemudian disusul responden dengan tingkat pendidikan Diploma dan SD/SMP. Pekerjaan dan pembayaran mobile yang digunakan juga didapatkan bervariasi. Hasil persentase secara keseluruhan karateristik responden tersebut dapat dicermati pada Tabel 1.

Tabel 1. Karateristik Responden

\begin{tabular}{|l|l|c|c|}
\hline $\begin{array}{c}\text { Karateristi } \\
\text { k }\end{array}$ & \multicolumn{1}{|c|}{ Item } & Jumlah & $\begin{array}{c}\text { Persentase } \\
(\%)\end{array}$ \\
\hline Jenis & a. Laki-laki & 137 & 56,4 \\
kelamin & b. Wanita & 106 & 43,6 \\
\hline Usia & a. $\leq 20$ Tahun & 144 & 59,3 \\
responden & b. 21-35 Tahun & 99 & 40,7 \\
& c. $\geq 35$ tahun & 0 & 0 \\
\hline Pendidikan & a. SD/SMP & 8 & 3,3 \\
terakhir & b. SMA/SMK & 162 & 66,7 \\
& c. Diploma/setara & 9 & 3,7 \\
& d. S1/setara & 60 & 24,7 \\
& e. S2 \& S3 & 4 & 1,6 \\
\hline Pekerjaan & a. Pelajar & 138 & 56,8 \\
& b. Karyawan & 30 & 20,6 \\
& c. Wirausaha & 25 & 12,3 \\
& d. Lain-lain & 110 & 10,3 \\
\hline Mobile & a. Gopay & 11 & 45,3 \\
payment & b. Ovo & 122 & 50,5 \\
& c. Keduanya & & \\
\hline
\end{tabular}

\section{Model Pengukuran}

Uji validitas dilakukan dengan melihat validitas konvergen dan diskriminan. Validitas konvergen diuji menggunakan nilai loading dari setiap item pernyataan pada variabel penelitian. Item pengukuran dapat dikatakan baik dan tidak memiliki masalah dengan validitas konvergen jika nilai loading-nya lebih besar dari 0,5 dan mengelompok ke masing-masing faktor atau variabel yang telah disebutkan pada penjelasan sebelumnya. Secara keseluruhan hasil pengujian menunjukkan bahwa semua item pengukuran dari variabel persepsi kegunaan, persepsi kemudahan menggunakan, sikap dan niat memiliki nilai faktor loading yang lebih besar dari 0,5. Oleh karena itu, dapat dikatakan bahwa indikator pada masing-masing variabel memiliki tingkat akurasi yang tinggi karena memiliki nilai muatan faktor indikator reflektif yang $\geq 0,5$. Lebih lengkapnya hasil pengujian validitas konvergen dapat dilihat pada Tabel 2.

Tabel 2. Hasil Pengujian Validitas dan reliabilitas

\begin{tabular}{|c|c|c|c|c|c|c|}
\hline \multirow{2}{*}{ Variabel } & Item & $\begin{array}{c}\text { Nilai } \\
\text { Loadin } \\
\text { g }\end{array}$ & AVE & SRAVE & $\begin{array}{c}\text { Conbach } \\
\text { alpha }\end{array}$ & $\begin{array}{c}\text { Composite } \\
\text { Reliability }\end{array}$ \\
\hline \multirow{3}{*}{$\begin{array}{c}\text { Pepsepsi } \\
\text { Kegunaan }\end{array}$} & PK1 & 0.809 & & & & \\
\cline { 2 - 3 } & PK2 & 0.809 & \multirow{2}{*}{0.587} & 0.766 & 0.758 & 0.848 \\
\cline { 2 - 3 } & PK3 & 0.841 & & & & \\
\cline { 2 - 3 } & PK4 & 0.576 & & & & \\
\hline
\end{tabular}




\begin{tabular}{|c|c|c|c|c|c|c|}
\hline \multirow{4}{*}{$\begin{array}{c}\text { Perpsepsi } \\
\text { Kemudahan } \\
\text { Menggunakan }\end{array}$} & PKM1 & 0.734 & \multirow{4}{*}{0.696} & \multirow{4}{*}{0.834} & \multirow{4}{*}{0.853} & \multirow{4}{*}{0.901} \\
\hline & PKM2 & 0.862 & & & & \\
\hline & PKM3 & 0.881 & & & & \\
\hline & PKM4 & 0.853 & & & & \\
\hline \multirow{4}{*}{ Sikap } & SIK1 & 0.827 & \multirow{4}{*}{0.686} & \multirow{4}{*}{0.828} & \multirow{4}{*}{0.847} & \multirow{4}{*}{0.897} \\
\hline & SIK2 & 0.827 & & & & \\
\hline & SIK3 & 0.812 & & & & \\
\hline & SIK4 & 0.846 & & & & \\
\hline \multirow{4}{*}{ Niat } & NI1 & 0.846 & \multirow{4}{*}{0.744} & \multirow{4}{*}{0.862} & \multirow{4}{*}{0.884} & \multirow{4}{*}{0.920} \\
\hline & NI2 & 0.914 & & & & \\
\hline & NI3 & 0.904 & & & & \\
\hline & NI4 & 0.778 & & & & \\
\hline
\end{tabular}

Pada penelitian ini, peneliti juga menggunakan nilai AVE dalam menguji validitas konvergen, dimana nilainya harus lebih besar dari $0,5 .{ }^{51}$ Nilai AVE di atas 0,5 akan menunjukkan bahwa suatu variabel tidak akan masuk variabel lain karena hanya akan masuk ke variabel yang sebenarnya. Tabel 2 menunjukkan bahwa semua variabel dalam penelitian ini memiliki nilai AVE di atas 0,5 yang secara berturut-turut sebesar $0.587,0.696,0.686$ dan 0.862 . Hal ini membuktikan bahwa semua variabel penelitian ini benar-benar berbeda satu sama lainnya dan telah memenuhi kriteria validitas konvergen yang baik.

Validitas diskriminan dilakukan dengan membandingkan nilai akar AVE (SRAVE) dari setiap variabel dengan korelasi antar variabel dalam penelitian ini. ${ }^{52}$ Model pengukuran dapat dikatakan memiliki validitas diskriminan yang baik jika nilai akar AVE dari setiap variabel lebih besar dari pada korelasi antar variabel yang satu dengan yang lainnya. Secara keseluruhan Tabel 3 menunjukkan bahwa setiap variabel memiliki nilai akar AVE yang lebih besar dari pada nilai korelasi antar variabel. Lebih lengkapnya hasil pengujian validitas diskriminan dapat dilihat pada tabel di bawah ini.

Tabel 3. Statistik Deskriptif dan Korelasi Antar Variabel

\begin{tabular}{|c|c|c|c|c|}
\hline Variabel & PK & PKM & SIK & NI \\
\hline Pepsepsi Kegunaan & 1 & & & \\
\hline $\begin{array}{c}\text { Perpsepsi Kemudahan } \\
\text { Menggunakan }\end{array}$ & $0.650^{\mathrm{a}}$ & 1 & & \\
\hline Sikap & $0.628^{a}$ & $0.637^{\mathrm{a}}$ & 1 & \\
\hline Niat & $0.595^{\mathrm{a}}$ & $0.582^{\mathrm{a}}$ & $0.694^{\mathrm{a}}$ & 1 \\
\hline
\end{tabular}

Uji reliabilitas dilakukan dengan menggunakan nilai composite reliability dan cronbach alpha dengan menggunakan nilai acuan lebih besar atau sama dengan $0,7 .{ }^{53}$ Hasil pengujian menunjukkan bahwa semua variabel pada penelitian ini memiliki nilai composite reliabitly dan cronbach alpha diatas 0,7 . Dengan begitu, semua variabel pada

${ }^{51}$ Hair, J.F., Hult, G.T.M., Ringle, C.M., \& Sarstedt, M. 2014. A premier on partial least squares structural equation modeling. USA: SAGE Publication.

${ }^{52}$ Ibid.

${ }^{53}$ Sholihin, M., \& Ratmono, D. 2013. Analisis SEM-PLS dengan warpPLS 3.0: untuk hubungan nonlinier dalam penelitian sosial dan bisnis. Yogyakarta, ANDI. 
penelitian ini dapat dikatakan reliabel. Secara terperinci hasil pengujian tersebut dapat dilihat pada Tabel 2.

\section{Model Struktural}

Pengujian model struktural dilakukan untuk melihat kesesuaian model penelitian ini dengan data yang ada. Kesesuaian tersebut dilihat dari beberapa indeks di bawah ini.

Tabel 4. Indeks Kesesuaian Model

\begin{tabular}{|c|c|c|}
\hline Indeks & Nilai & Kriteria \\
\hline APC & 0.491 & $\mathrm{P}<0.001$ \\
\hline ARS & 0.492 & $\mathrm{P}<0.001$ \\
\hline AARS & 0.489 & $\mathrm{P}<0.001$ \\
\hline AVIF & 1.775 & Ideally $<=3.3$ \\
\hline AFVIF & 2.186 & Ideally $<=3.3$ \\
\hline SPR & 1.000 & Ideally $=1$ \\
\hline RSCR & 1.000 & Ideally $=1$ \\
\hline SSR & 1.000 & Acceptable if $>0,7$ \\
\hline NLBCDR & 1.000 & Acceptable if $>0,7$ \\
\hline
\end{tabular}

Hasil pengujian menunjukan bahwa semua indeks memiliki nilai yang disyaratkan oleh masing-masing indeks yaitu nilai APC, ARS, AARS, AVIF dan AFVIF masing-masing mendapatkan nilai berturut-turut 0.491, 0.492, 0.489, 1.775 dan 2.186. Selanjutnya, indeks SPR, RSCR, SSR dan NLBCDR masing-masing mendapatkan nilai 1.000 yang sesuai dengan syarat dan kriteria pengujian. Selain itu, peneliti juga menggunakan koefisien determinasi $\left(\mathrm{R}^{2}\right)$ untuk melihat seberapa besar variabel endogen dapat dijelaskan oleh variabel-variabel exogennya. Nilai $\mathrm{R}^{2}$ dalam penelitian ini ditemukan sebesar 0,50 dan 0,49. Artinya, 50\% varians dari sikap menggunakan pembayaran mobile dapat dijelaskan oleh beberapa variabel endogen yaitu persepsi kegunaan dan persepsi kemudahan menggunakan. Sedangkan $49 \%$ varians dari niat menggunakan pembayaran mobile dapat dijelaskan oleh sikap menggunakan pembayaran mobile. Oleh karena itu, dapat disimpulkan bahwa model struktural dalam penelitian ini dapat dikatakan telah memenuhi kriteria goodness of fit yang sangat baik.

Pengujian hipotesis dilakukan dengan melihat nilai koefisien jalur $(\beta)$ atau bobot regresi dan $p$-value dari setiap jalur yang telah dibangun berdasarkan teori dan pengembangan hipotesis sebelumnya seperti yang terlihat pada Gambar 2.

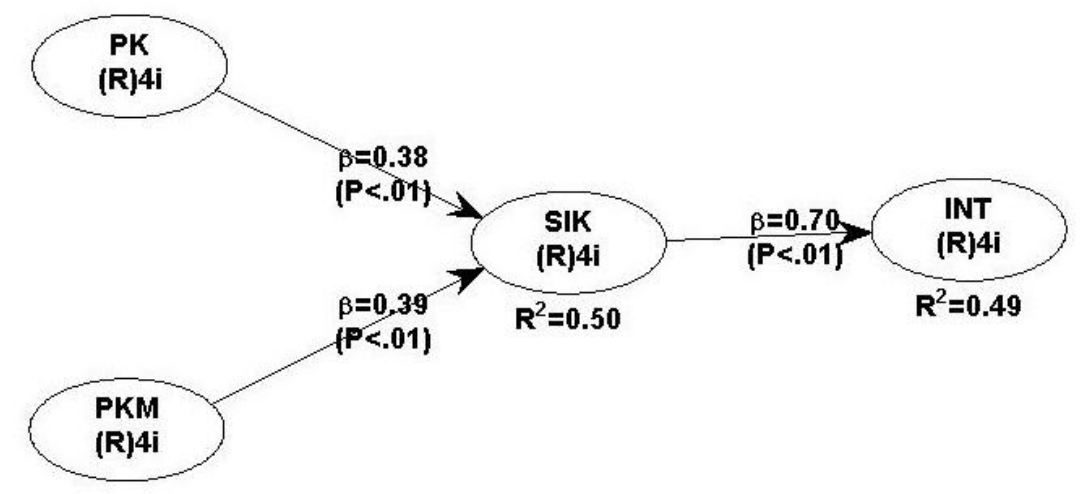




\section{Gambar 2. Model, Hipotesis dan Hasil Penelitian}

Hasil pengujian model struktural di atas menunjukkan bahwa koefisien jalur pada pengaruh persepsi kegunaan dan persepsi kemudahan menggunakan terhadap sikap ditemukan signifikan secara statistik pada tingkat $1 \%(\beta=0,38, p$-value $<0,01)$ dan $(\beta=0,39 p$-value $<0,01)$. Koefisien jalur pada pengaruh sikap terhadap niat juga ditemukan signifikan secara statistik pada tingkat $1 \%(\beta=0,70, p$-value $<0,01)$.

\section{Diskusi}

Hasil penelitian ini menunjukkan bahwa manfaat dari pembayaran mobile mampu memberikan pandangan atau sikap positif di mata para penggunannya. Hal ini terlihat dari hasil statistik yang menunjukkan nilai koefisien dan $p$-value jalur yang telah diuji yaitu $\beta=0,38, p$-value $<0,01$, sehingga hipotesis 1 didukung.

Hasil penelitian ini didukung dengan beberapa penelitian terdahulu. Aslam et al., (2017) Schierzet et al., (2010) dan Chuang et al.,(2016) menemukan bahwa manfaat yang diberikan oleh pembayaran mobile akan berguna dan menunjang aktivitas individu, sehingga mereka cenderung akan menunjukkan sikap yang positif terhadap pembayaran mobile. ${ }^{54,55,56} \mathrm{Hal}$ ini juga dibuktikan dengan beberapa penelitian terdahulu yang menemukan bahwa persepsi kegunaan berpengaruh positif dengan sikap seseorang terhadap suatu teknologi. ${ }^{57}$ Dengan begitu, hasil penelitian terdahulu sejalan dengan hasil penelitian ini yang menemukan pengaruh persepsi kegunaan terhadap sikap individu terhadap suatu teknologi khususnya pembayaran mobile. Selain itu, hasil penelitian ini juga sejalan dengan padangan TAM yang mengatakan bahwa sikap seseorang terhadap suatu teknologi didorong oleh manfaat yang diberikan teknologi tersebut untuk menunjang aktivitas mereka. ${ }^{58,59}$

Hasil penelitian ini menunjukkan bahwa kemudahan menggunakan pembayaran mobile mampu memberikan pandangan atau sikap positif di mata para penggunannya. Hal ini terlihat dari hasil statistik yang menunjukkan nilai koefisien dan $p$-value jalur yang telah diuji yaitu $\beta=0,39, p$-value $<0,01$, sehingga hipotesis 2 didukung.

Hasil penelitian ini didukung dengan beberapa penelitian terdahulu. Aslam et al., (2017) dan Schierzet et al., (2010) menuemukan bahwa persepsi kemudahan menggunakan pembayaran mobile mampu membangun sikap positif seseorang terhadap teknologi, karena mereka merasa bahwa penggunaan teknologi tersebut tidak sudah dan tidak membingungkan. ${ }^{60,61} \mathrm{Hal}$ ini juga dibuktikan dengan beberapa penelitian terdahulu yang menemukan bahwa persepsi kemudahan menggunakan berpengaruh positif dengan

${ }^{54}$ Aslam, W., Ham, M., \& Arif, I. 2017. Consumer Behavioral Intentions towards Mobile Payment Services: An Empirical Analysis in Pakistan. Market. Tržište, 29 (2), 161-176.

${ }^{55}$ Schierz, P. G., Schilke, O., \& Wirtz, B. W. 2010. Understanding consumer acceptance of mobile payment services: An empirical analysis. Electronic commerce research and applications, 9(3), 209-216.

${ }^{56}$ Chuang L-M, Liu C-C, \& Kao H-K. 2016 The adoption of fintech service: TAM perspective. Int J Manag Adm Sci $3: 1-15$.

${ }^{57}$ Shanmugam, A., Savarimuthu, M., \& Wen, T. 2014. Factors Affecting Malaysian Behavioral Intention to Use Mobile Banking With Mediating Effects of Attitude. Academic Research International, 5(2), 236-253.

${ }^{58}$ Davis, F.D., Bagozzi, R.P., \& Warshaw, P.R. 1989. User acceptance of computer technology: a comparison of two theoretical models. Management Science, 35, 982-1003.

${ }^{59}$ Davis, F.D. 1989. Perceived usefulness, perceived ease of use, and user acceptance of information technology. MIS Quarterly, 13, 319-340.

${ }_{60}$ Aslam, W., Ham, M., \& Arif, I. 2017. Consumer Behavioral Intentions towards Mobile Payment Services: An Empirical Analysis in Pakistan. Market. Tržište, 29 (2), 161-176.

${ }^{61}$ Schierz, P. G., Schilke, O., \& Wirtz, B. W. 2010. Understanding consumer acceptance of mobile payment services: An empirical analysis. Electronic commerce research and applications, 9(3), 209-216. 
sikap seseorang terhadap suatu teknologi. ${ }^{62}$ Dengan begitu, hasil penelitian terdahulu sejalan dengan hasil penelitian ini yang menemukan pengaruh persepsi kegunaan terhadap sikap individu terhadap suatu teknologi khususnya pembayaran mobile. Selain itu, hasil penelitian ini juga sejalan dengan padangan TAM yang mengatakan bahwa sikap seseorang terhadap suatu teknologi didorong oleh kemudahan dalam menggunakan teknologi tersebut sehingga tidak membutuhkan banyak usaha dalam mengoperasikannya. ${ }^{63,64}$

Hasil penelitian ini menunjukkan bahwa sikap pengguna berpengaruh secara signifikan terhadap niat menggunakan pembayaran mobile. Hal ini terlihat dari hasil statistik yang menunjukkan nilai koefisien dan $p$-value jalur yang telah diuji yaitu $\beta=$ $0,70, p$-value $<0,01$, sehingga hipotesis 3 didukung.

Hasil penelitian ini didukung dengan beberapa penelitian terdahulu. Chaung et al., (2015), Venkatesh and Davis (2000) dan Davis et al., (1989) mengatakan bahwa niat seseroang dalam menggunakan suatu teknologi bergantung pada sikap mereka terhadap teknologi tersebut. ${ }^{65,66,67}$ Ketika pengguna merasakan dampak positif dengan kehadiran sistem pembayaran mobile akan membuat individu tersebut memiliki niat yang kuat segera menggunakan sistem tersebut. Hal tersebut telah dibuktikan secara empiris yang menemukan bahwa sikap berpengaruh positif terhadap niat menggunakan suatu teknologi. ${ }^{68,69,70,71,72}$ Dengan begitu, hasil penelitian terdahulu sejalan dengan hasil penelitian ini yang membuktikan bahwa niat individu dalam menggunakan pembayaran mobile ditentukan oleh sikap mereka dalam menggunakan suatau teknologi khususnya penggunaan pembayaran mobile. Hasil penelitian ini juga sejalan dengan pandangan TAM yang bahwa niat seseorang dalam menerima dan menggunakan suatu teknologi ditentukan oleh isikap mereka terhadap teknologi tersebut. ${ }^{73,74,75}$

\section{Kesimpulan}

Hasil penelitian ini memberikan bukti baru mengenai penyebab seseorang mau menggunakan suatu teknologi khususnya pada sistem pembayaran mobile. Hasil penelitian ini menunjukkan TAM yang terdiri atas persepsi kegunaan dan persepsi

\footnotetext{
${ }^{62}$ Shanmugam, A., Savarimuthu, M., \& Wen, T. 2014. Factors Affecting Malaysian Behavioral Intention to Use Mobile Banking With Mediating Effects of Attitude. Academic Research International, 5(2), 236-253.

${ }^{63}$ Davis, F.D., Bagozzi, R.P., \& Warshaw, P.R. 1989. User acceptance of computer technology: a comparison of two theoretical models. Management Science, 35, 982-1003.

${ }^{64}$ Davis, F.D. 1989. Perceived usefulness, perceived ease of use, and user acceptance of information technology. MIS Quarterly, 13, 319-340.

${ }^{65}$ Chuang L-M, Liu C-C, \& Kao H-K. 2016 The adoption of fintech service: TAM perspective. Int J Manag Adm Sci $3: 1-15$.

${ }^{66}$ Venkatesh, V., \& Davis, F.D. 2000. A theoretical extention of the technology acceptance model: four longitudinal field studies. Management Science, 46, 186-204.

${ }^{67}$ Davis, F.D., Bagozzi, R.P., \& Warshaw, P.R. 1989. User acceptance of computer technology: a comparison of two theoretical models. Management Science, 35, 982-1003.

${ }^{68}$ Bauer, H. H., Reichardt, T., \& Schüle, A. 2005. User requirements for location based services. Proceedings of the IADIS International Conference in e Commerce, Porto, 211-218.

${ }^{69}$ Suntornpithug N, \& Khamalah J. 2010. Machine and person interactivity: the driving forces behind influences on consumers' willingness purchase online. J Electron Commer Res 11(4):299-325.

${ }^{70}$ Meharia, P. 2012. Assurance on the reliability of mobile payment system and its effects on its' use: an empirical examination. Account Manag Inf Syst Contab Si Inf De Gestiune 11(1):97-111. 12(2):165-187.

${ }^{71}$ Lorenzo-Romero C, Del Chiappa G. 2013 Adoption of social networking sites by Italian. Inf Syst e-Bus Manag

${ }^{72}$ Lie bana-Cabanillas F, Muñoz-Leiva F, \& Sa'nchez-Ferna'ndez J. 2015. Payment systems in new electronic environments: consumer behavior in payment systems via SMS. Int J Inf Technol Decis Mak 14:1-29.

${ }^{73}$ Davis, F.D., Bagozzi, R.P., \& Warshaw, P.R. 1989. User acceptance of computer technology: a comparison of two theoretical models. Management Science, 35, 982-1003.

${ }^{74}$ Davis, F.D. 1989. Perceived usefulness, perceived ease of use, and user acceptance of information technology. MIS Quarterly, 13, 319-340.

${ }^{75}$ Venkatesh, V., \& Davis, F.D. 2000. A theoretical extention of the technology acceptance model: four longitudinal field studies. Management Science, 46, 186-204.
} 
kemudahan menggunakan berpengaruh positif dan signifikan terhadap sikap menggunakan pembayaran mobile. Hal ini terjadi karena manfaat dan kemudahan dalam menggunakan sistem pembayaran mobile mampu mendorong individu menunjukkan sikap positif terhadap penggunaan sistem tersebut. Lebih jauh, individu hanya akan menerima suatu teknologi jika teknologi memberikan manfaat, mudah untuk digunakan, prosesnya sederhana dan tidak membingungkan bagi para penggunaanya. Penelitian ini juga mengkomfirmasi pandangan TAM yang menyatakan bahwa niat seseorang terhadap teknologi sangat bergantung pada sikap mereka terhadap teknologi tersebut. Dengan kata lain, niat individu menggunakan pembayaran mobile bergantung pada sikap positif mereka terhadap sistem tersebut.

Hasil penelitian ini juga diharapkan dapat memberikan masukan bagi semua perusahaan baik di perusahaan jasa maupun perusahaan barang jadi untuk mengadopsi sistem pembayaran mobile agar dapat memberikan sistem pembayaran yang menekankan kemudahan dalam melakukan transaksi kepada pelanggan. Dengan kata lain, setiap perusahaan harus ikut bagian dalam perubahan sistem pembayaran dengan cara masuk ke ekosistem yang sudah terbentuk saat ini yaitu ekosistem gopay, ovo dan lain sebagainya. Penelitian ini juga diharapkan dapat memberikan informasi bagi para pemasar bahwa manfaat dan kemudahan dalam menggunakan suatu teknologi menjadi faktor penentu seseorang mau dan mengadopsi sistem pembayaran mobile.

\section{Pernyataan}

Penelitian ini dibiayai oleh Kementrian, Riset dan Teknologi sesuai dengan kontrak Penelitian Tahun Anggaran 2021 dngan No. kontrak 065/SP2H/LT/DPRM/2021 tanggal 18 Maret 2021

\section{Daftar pustaka}

\section{Buku:}

Ajzen, I, and M Fishbein. 1980. Understanding Attitudes and Predicting Social Behavior. New Jersey: Prentice-Hall.

Allport, G. W. 1935. "Attitudes. In C. M. Murchison (Ed.).” In Handbook of Social Psychology. Winchester: Clark University Press.

Dapp. 2014. Fintech-The Digital (r)Evolution in the Financial Sector. Frankfurt: Deutche Bank Research.

Ghozali, I, and Fuad. 2005. Structural Equation Modelling: Teori, Konsep Dan Aplikasi. Semarang: Badan Penerbit Universitas Diponegoro.

Hair Jr, J F, G T M Hult, C M Ringle, and M Sarstedt. 2014. A Premier on Partial Least Squares Structural Equation Modeling (PLS-SEM). SAGE Publication. USA: SAGE Publication.

Sholihin, M, and D Ratmono. 2013. Analisis SEM-PLS Dengan WarpPLS 3.0: Untuk Hubungan Nonlinier Dalam Penelitian Sosial Dan Bisnis. Yogyakarta: ANDI.

Sugiyono. 2015. Metode Penelitian: Kuantitatif, Kualitatif Dan R\&D. Bandung: Alfabeta.

\section{Jurnal:}

Arner, D. W, J. Barberis, and R. P Buckley. 2015. "The Evolution of FinTech: A New Post-Crisis Paradigm?" University of Hong Kong Faculty of Law Research Paper.

Aslam, W, M Ham, and I Arif. 2017. "Consumer Behavioral Intentions towards Mobile Payment Services: An Empirical Analysis in Pakistan.” Trziste 29 (2): 161-76. 
Bauer, H. H, T Reichardt, and A Schüle. 2005. "User Requirements for Location Based Services." Proceedings of the IADIS International Conference in e Commerce, 211-18.

Berakon, I., Aji, H.M. and Hafizi, M.R. (2021), "Impact of digital Sharia banking systems on cash-waqf among Indonesian Muslim youth", Journal of Islamic Marketing, https://doi.org/10.1108/JIMA-11-2020-0337

Chuang, L-M, C-C Liu, and H-K Kao. 2016. "The Adoption of Fintech Service: TAM Perspective." International Journal of Management and Administrative Sciences 3 (7): $1-15$.

Dahlberg, T, N Mallat, J Ondrus, and A Zmijewska. 2008. "Past, Present and Future of Mobile Payments Research: A Literature Review." Electronic Commerce Research and Applications 7 (2): 165-81.

Dastan, İ, and C Gürler. 2016. "Factors Affecting the Adoption of Mobile Payment Systems: An Empirical Analysis.” Emerging Markets Journal 6 (1): 16-24.

Davis, Fred D., Richard P. Bagozzi, and Paul R. Warshaw. 1989. "User Acceptance of Computer Technology: A Comparison of Two Theoretical Models." Management Science 35 (8): 982-1003.

Davis, Fred D. 1989. "Perceived Usefulness, Perceived, And User Acceptance." MIS Quarterly 13 (3): 319-39.

Fishbein, M. 1963. "An Investigation of the Relationship between Beliefs about an ObJect and the Attitude toward That Object." Human Relations 16 (3): 233-39.

Gefen, D, E Karahanna, and D.W Straub. 2017. "Trust and TAM in Online Shopping: An Integrated Model." MIS Quarterly 27 (1): 51-90.

Guriting, P, and N. O Ndubisi. 2006. "Borneo Online Banking: Evaluating Customer Perceptions and Behavioural Intention.” Management Research News 29 (1/2): 615.

Lie’bana-Cabanillas, F, F Muñoz-Leiva, and J Sa'nchez-Ferna'ndez. 2015. "Payment Systems in New Electronic Environments: Consumer Behavior in Payment Systems via SMS." International Journal of Information Technology \& Decision Making 14 (2): 421-49.

Lorenzo-Romero, C, and G Del Chiappa. 2013. "Adoption of Social Networking Sites by Italian." Information Systems and E-Business Management 12 (2): 165-87.

McAuley, D. 2014. "What Is FinTech? Wharton FinTech."

Meharia, P. 2012. "Assurance on the Reliability of Mobile Payment System and Its Effects on Its' Use: An Empirical Examination." Journal of Accounting and Management Information Systems 11 (1): 97-111.

Moon, J. W, and Y. G Kim. 2001. "Extending the TAM for a World-Wide-Web Context." Information and Management 38 (4): 217-30.

Porter, M E. 2001. "Strategy and the Internet." Harvard Business Review, no. march: $62-78$.

Ramayah, T, and N. M Suki. 2006. "Intention to Use Mobile PC among MBA Students: Implications for Technology Integration in the Learning Curriculum." UNITAR EJournal 1 (2): 1-10.

Riza, Alex Fahrur; Hafizi, Muhammad Riza (2020). Customers attitude toward Islamic mobile banking in Indonesia: Implementation of TAM. Asian Journal of Islamic Management, pp. 75-84, doi:https://doi.org/10.20885/ajim.vol1.iss2.art1

Schierz, P. G, O Schilke, and B. W Wirtz. 2010. "Understanding Consumer Acceptance of Mobile Payment Services: An Empirical Analysis.” Electronic Commerce 
Research and Applications 9 (3): 209-16.

Shanmugam, A, M Savarimuthu, and T Wen. 2014. "Factors Affecting Malaysian Behavioral Intention to Use Mobile Banking With Mediating Effects of Attitude." Academic Research International 5 (2): 236-53.

Suntornpithug, N, and J Khamalah. 2010. "Machine and Person Interactivity: The Driving Forces behind Influences on Consumers' Willingness Purchase Online." Journal Electronic Commerce Research 11 (4): 299-325.

Taylor, S, and P. A Todd. 1995. "Understanding Information Technology Usage: A Test of Competing Models." Information Systems Research 6 (2): 144-76.

Venkatesh, V, and F D Davis. 2000. "Theoretical Extension of the Technology Acceptance Model: Four Longitudinal Field Studies." Management Science 46 (2): 186-204. https://doi.org/10.1287/mnsc.46.2.186.11926.

Zhu, D, C. T Linb, and Y Hsu. 2012. "Using the Technology Acceptance Model to Evaluate User Attitude and Intention of Use for Online Games." Total Quality Management \& Business Excellence 23 (7-8): 965-80.

\section{Website:}

APJII. 2016. "Penetrasi \& Profil Perilaku Pengguna Internet Indonesia 2016." Apjii.

. 2017. "Penetrasi \& Profil Perilaku Pengguna Internet Indonesia 2017." Apjii, 51.

https://apjii.or.id/survei2018s/download/TK5oJYBSyd8iqHA2eCh4FsGELm3ubj.

Edy, S.P. 2016. "Kegiatan Pembayaran Gaya Baru Dalam Dunia 'Fintech."” Kompas.Com.

2016.

https://money.kompas.com/read/2016/12/06/132215426/kegiatan.pembayaran.gaya .baru.dalam.dunia.fintech.?page=all. 